\title{
Study on the Non-Energy Benefit (NEB) of Area-Wide Energy Utilization and Evaluation of the Marginal Abatement Cost
}

\author{
Ryota Kuzuki $^{1,{ }^{*}}$, Shuzo Murakami ${ }^{2}$, Toshiharu Ikaga ${ }^{3}$, Satoru Sadohara ${ }^{4}$, Satoshi Yoshida ${ }^{4}$, \\ Toru Ichikawa ${ }^{1}$, Yoshio Kato ${ }^{5}$, Tsutsumi Tanaka ${ }^{5}$, Yuichi Ikuta ${ }^{6}$, Ken Aozasa ${ }^{7}$ \\ ${ }^{1}$ Tokyo Gas Co., Ltd., Tokyo, Japan, $\quad{ }^{2}$ Building Research Institute, Tsukuba, Japan \\ ${ }^{3}$ Keio University, Yokohama, Japan, $\quad{ }^{4}$ Yokohama National University, Yokohama, Japan \\ ${ }^{5}$ Nihon Sekkei Co., Ltd., Tokyo, Japan, ${ }^{6}$ Japan Environmental Systems Co., Ltd., Tokyo, Japan \\ ${ }^{7}$ Institute of Building Environment and Energy Conservation, Tokyo, Japan \\ *Corresponding author. Tel: +81 354007752 Fax: +81 54007766,E-mail: kuzuki@tokyo-gas.co.jp
}

\begin{abstract}
To achieve the Kyoto Protocol target of carbon reduction in Japan, additional measures beyond individual building-scale are strongly required. Area-wide energy utilization is expected to play an important role, not only in improving energy efficiency, but also in enhancing utilization of renewable energy and unused thermal energy toward a low-carbon society. But so far there have been few initiatives that have been realized. One of the major hurdles is the lack of methods to convince stakeholders to collaborate towards implementation. This study focuses on non-energy benefits (NEBs), which are indirect benefits such as stimulating regional economies and environmental protection, as distinguished from the direct energy-benefit (EB) of utility costs reduction.
\end{abstract}

Through the development of methods to classify and quantify various NEBs and to assign monetary values in the marginal abatement cost (MAC), area-wide energy utilization has been deemed to be more competitive among various carbon reduction measures. Customized marginal abatement cost curve evaluation has proven effective for encouraging stakeholders to implement.

Keywords: Area-wide energy utilization, Non-energy benefit, Marginal abatement cost, Cost benefit ratio, Payback time

\section{Introduction}

\subsection{Area-wide energy utilization of scale measures for carbon reduction}

In the commercial and residential sectors, further reductions of carbon emissions are being sought toward the realization of a low-carbon society. To respond to this issue, area-wide carbon-emission reduction measures must be promoted for blocks of buildings, communities, districts and for cities, which go beyond individual buildings. The Kyoto Protocol Target Achievement Plan $^{1)}$ in Japan begins with area-wide energy utilization as its first measure, in terms of further energy saving beyond individual buildings and for promoting a large increase in the utilization of neighboring unused energy sources and renewable energy sources.

\subsection{Necessity of evaluating measures from a middle-to-long-term perspective, considering local characteristics}

In 2008, the Mid-term Targets

Examination-Committee of the

Cabinet Secretariat's Council on

the Global Warming Issue

(hereafter, the "Mid-term Targets

Committee") discussed measures

for the nation to reduce carbon

emissions over the middle term

through marginal abatement cost (MAC). ${ }^{2)}$

The image is shown in Fig.1.

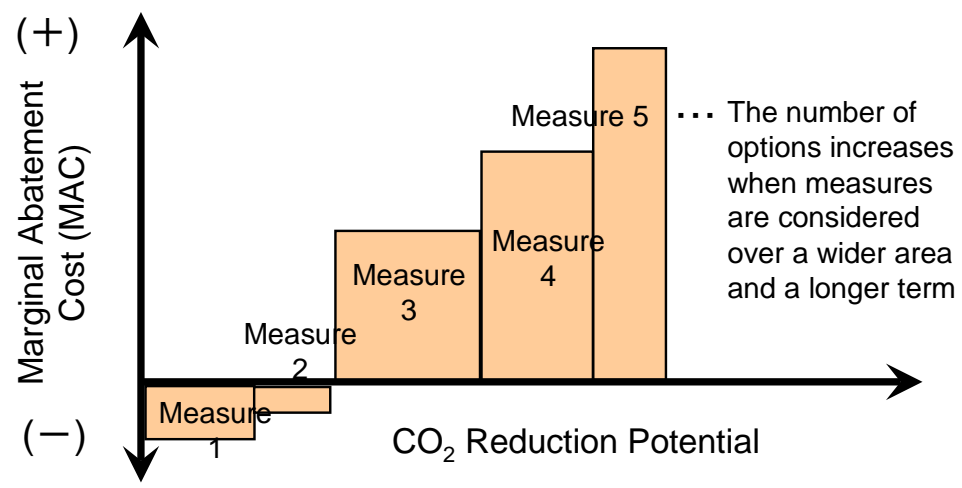

Figure 1 Marginal abatement cost curve (image) 
MAC is defined as the cost required per additional unit reduction of $\mathrm{CO}_{2}$ (e.g., per ton $\mathrm{CO}_{2}$ ) from the present conditions, under a given area (e.g worldwide, nationwide, district-wide, etc.). McKinsey \& Company ${ }^{3)}$ and some other organizations have evaluated the MAC of a variety of carbon reduction measures and have published reports presenting MAC curves, which is a useful method to determine the selection of cost-effective measures. However, for discussions on area-wide energy utilization, the current evaluation method has some problems, as listed below;

1) Measures whose costs vary greatly due to distinct regional characteristics (such as differences in energy infrastructure and in access to locally generated, locally consumed energy) are too detailed to discuss on a nationwide scale.

2) Measures which require large initial investments, but which are effective for a long time (such as insulation of buildings and infrastructure development) are evaluated as comparatively expensive options if the payback time is set at a relatively short uniform period.

3) MAC has been defined as the net cost of measures, deducting direct energy benefits (EB) of energy-utilities cost reduction from the total costs. However, even if there are also diverse indirect benefits, such as stimulation of regional economies and environmental protection resulting from the measures, which some researches collectively refer to as "non-energy benefits" (NEBs) ${ }^{4), 5)}$, they have not been considered in the MAC evaluation.

\subsection{Research objectives}

The objective of this research is to establish methods of accurately determining area-wide energy utilization in comparison with other carbon reduction measures, and methods of evaluating cost-benefit ratios (B/C) and MAC, focusing on non-energy benefits (NEBs) in order to encourage stakeholders to implement.

\section{Methodology}

\subsection{Estimation of $\mathrm{CO}_{2}$ reduction potential considering the regional characteristics}

Specifying the particular region where the measures for a low-carbon society will be advanced clarifies the specific figures concerning any unused energy sources (incinerationplant waste heat, etc.) that can be accessed in the concerned district, such as solar heat collectors and photovoltaic power generation equipment in accordance with heat and electricity-demand density and patterns according to time band, and on-site cogeneration. Those figures are then used to calculate the $\mathrm{CO}_{2}$ reduction potential of the concerned district. The initial and running costs of each measure are set referring to prior knowledge ${ }^{2), 6)}$ published by the Japanese government. The values for measures with different costs by region, by necessity, are set on a case-by-case basis. Subsidies and other grants are not included.

\subsection{Setting the payback time considering the duration of the measure's effects}

The MAC of each measure is calculated as the annual cost ([yen/year] / [t- $\mathrm{CO}_{2} /$ year]) under the following procedure; considering the initial costs (including renewal costs) for implementing each carbon-emission reduction measure, the running costs, and the reduction in utilities expenses gained from energy conservation. The expressions of the procedure are as follows, and Fig.2 presents an image of the MAC structure.

The payback time should be set appropriately for each measure from the viewpoint of the middle-term and long-term improvement of social capital and with consideration for the 
technology use conditions. Referring to the option that the National Institute for Environmental Studies proposed to the Mid-term Targets Committee (a setting of $50-70 \%$ of the functional lifetime of each measure ${ }^{2)}$, McKinsey \& Company report ${ }^{3)}$, in this study the payback time is set at a number of years equivalent to $70 \%$ of the lifetime of each measure.

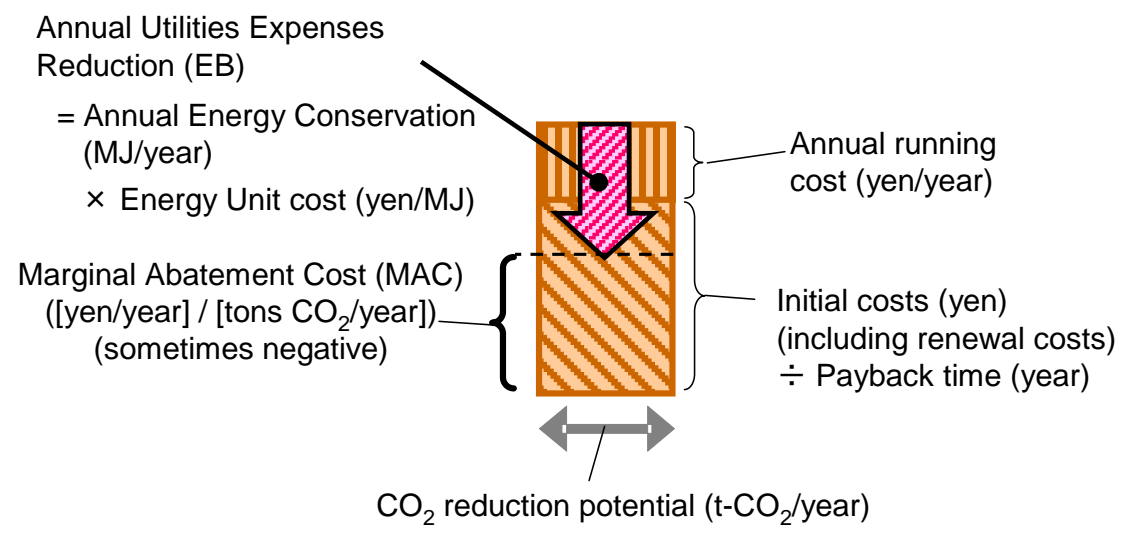

Fig. 2. Structure of marginal abatement cost (MAC) of a carbon reduction measure

Table 1 presents a summary of the classification of $\mathrm{CO}_{2}$ reduction measures and their MAC.

Table 1. Carbon reduction measures and MAC setting by measures

\begin{tabular}{|c|c|c|c|c|c|c|c|}
\hline & \multirow{2}{*}{$\begin{array}{l}\text { Carbon reduction measures in this study } \\
\text { (Set based on the } 2008 \text { Local Government } \\
\text { White Paper (Japan) on the Environment) }\end{array}$} & \multicolumn{2}{|c|}{$\begin{array}{l}\text { MAC and payback } \\
\text { time under prior } \\
\text { Knowledge } 2 \text { 2),6) }\end{array}$} & \multicolumn{4}{|c|}{$\begin{array}{c}\text { Proposed MAC with payback time } \\
\text { set at } 70 \% \text { of functional lifetime } \\
\text { of each measure }\end{array}$} \\
\hline & & $\begin{array}{l}\text { MAC } \\
(\text { yen/ } \\
\left.\text { t- } \mathrm{CO}_{2}\right)\end{array}$ & $\begin{array}{l}\text { Payback } \\
\text { time } \\
\text { (years) }\end{array}$ & $\begin{array}{l}\mathrm{MAC} \\
(\mathrm{yen} / \\
\left.\mathrm{t}-\mathrm{CO}_{2}\right)\end{array}$ & $\begin{array}{l}\text { Payback } \\
\text { time } \\
\text { (years) }\end{array}$ & \multicolumn{2}{|c|}{$\begin{array}{l}\text { References } \\
\text { of lifetime }\end{array}$} \\
\hline \multicolumn{8}{|c|}{ Commercial Sector } \\
\hline (1) & Air conditioning equipment efficiency improvements & $-24,000$ & 3 & $-24,000$ & 10.5 & 15 & + \\
\hline (2) & Lighting efficiency improvements, etc. & $-25,000$ & 3 & $-25,000$ & 14.0 & 20 & t \\
\hline (3) & Power and other efficiency improvements & 19,000 & 3 & $-16,491$ & 17.5 & 25 & t \\
\hline (4) & High-efficiency water heaters & 32,000 & 3 & 0 & 10.5 & 15 & ${ }^{*}$ \\
\hline (5) & Improved insulation in newly constructed buildings & 69,000 & 9 & 16,143 & 21.0 & 30 & 2 t末t \\
\hline (6) & Improved insulation in existing buildings & 69,000 & 9 & 35,964 & 14.0 & 20 & 2 tha \\
\hline (7) & Building and energy management systems (BEMS) & 3,000 & 8 & 8.714 & 7.0 & 10 & ${ }^{*}$ \\
\hline (8) & Use of solar thermal energy & 2,000 & 10 & 2,000 & 11.9 & 17 & t\#\# \\
\hline (9) & Photovoltaic power generation & 62,000 & 9 & 23,378 & 11.9 & 17 & ${ }^{* *}$ \\
\hline (10) & Changes in work styles & $-38,000$ & - & $-38,182$ & - & - & \#*t \\
\hline (11) & Commercial cogeneration & $-8,500$ & 10 & $-8,500$ & 10.5 & 15 & 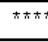 \\
\hline \multicolumn{8}{|c|}{ Residential Sector } \\
\hline$(12)$ & Heating-and-cooling efficiency improvements & $-30,000$ & 3 & $-30,000$ & 4.2 & 6 & ${ }^{* *}$ \\
\hline (13) & Lighting efficiency improvements, etc. & $-28,000$ & 3 & $-34,789$ & 14.0 & 20 & * \\
\hline (14) & Household appliances' efficiency improvements & 28,000 & 3 & 10,629 & 4.2 & 6 & ${ }^{* *}$ \\
\hline (15) & High-efficiency water heaters & 143,000 & 3 & 11,343 & 7.0 & 10 & * \\
\hline (16) & Improved insulation in newly constructed housing & 430,000 & 9 & 239,870 & 15.4 & 22 & ${ }^{* *}$ \\
\hline (17) & Improve existing insulation & 430,000 & 9 & 266,607 & 14.0 & 20 & t末太 \\
\hline (18) & Home energy management systems (HEMS) & $-2,000$ & 3 & $-18,457$ & 7.0 & 10 & ${ }^{*}$ \\
\hline (19) & Solarwater heaters & 17,000 & 8 & $-22,328$ & 11.9 & 17 & $\pi \hbar$ \\
\hline$(20)$ & Photovoltaic power generation & 78,000 & 10 & 59,319 & 11.9 & 17 & t* \\
\hline (21) & Changes in life styles & $-38,000$ & - & $-38,000$ & - & - & \#\#+ \\
\hline (22) & Residential cogeneration & 30,000 & 10 & 30,000 & 7.0 & 10 & ${ }^{*}$ \\
\hline \multicolumn{8}{|c|}{ Community-Wide Energy Utilization } \\
\hline (23) & Wind power generation & 12,000 & - & 12,000 & 11.9 & 17 & ${ }^{* *}$ \\
\hline (24) & Woody biomass & 4,000 & 20 & 4,000 & 14.0 & 20 & 万大स木 \\
\hline (25) & Waste products power generation & 2,000 & - & 2,000 & 14.0 & 20 & 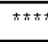 \\
\hline (26) & Heat-and-electric power exchange among buildings ${ }^{* \star \star \star}$ & - & - & 17,488 & 14.0 & 20 & tהt \\
\hline (27) & Incineration plant waste heat ${ }^{t+\hbar+\hbar}$ & $\begin{array}{r}16,616- \\
28,329\end{array}$ & 20 & $\begin{array}{r}9,890- \\
14,925\end{array}$ & 31.5 & 45 & \#*A+ \\
\hline (28) & Regional cogeneration ${ }^{\star \hbar \star \star \hbar}$ & 2,586 & 15 & $-2,082$ & 21.0 & 30 & 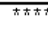 \\
\hline
\end{tabular}




\subsection{Definition and Monetizing NEBs}

As described above, there are various NEBs among the carbon reduction measures received by the stakeholders. In terms of the way of estimating monetary value, the classification and quantification of the NEBs are proposed. Five major categories are defined (a - e), and they are additionally classified into fourteen categories. Table 2 shows the details.

Table 2. Monetization of EB and NEBs by category

\begin{tabular}{|c|c|c|}
\hline Benefit & Monetization Outline & Referenceis \\
\hline \multicolumn{3}{|l|}{$<$ Energy Benefit $(\mathrm{EB})>$} \\
\hline Reduction in utilities expenses & $\begin{array}{l}\text { Reduction in utilities expenses (yen/year) } \\
=\text { energy reduction volume (yen/year) } \\
\mathrm{X} \text { energy unit cost (yen/MJ) }\end{array}$ & $\begin{array}{l}\text { Energy unit cost set based on supply agreements and } \\
\text { supplementary supply agreements from city gas and electric } \\
\text { power utilities }\end{array}$ \\
\hline \multicolumn{3}{|l|}{$<$ Non-Energy Benefit (NEB) $>$} \\
\hline \multicolumn{3}{|c|}{ a. Benefit from creation of environmental value } \\
\hline a1. $\mathrm{CO} 2$ reduction value & $\begin{array}{l}\mathrm{CO}_{2} \text { reduction value (yen/year) } \\
=\mathrm{CO}_{2} \text { reduction amount }\left(\mathrm{t}-\mathrm{CO}_{2} / \text { year) }\right. \\
\quad \mathrm{XC \textrm {O } _ { 2 }} \text { price (yen/t- } \mathrm{CO}_{2} \text { ) }\end{array}$ & $\begin{array}{l}\mathrm{CO}_{2} \text { price set (e.g., 4,000yen/t-CO2) } \\
\text { "Point Carbon "Carbon 2009" (March 2009)" }\end{array}$ \\
\hline a2. Green energy creation value & $\begin{array}{l}\text { Green energy creation value (yen/year) } \\
=\text { green energy use volume }(\mathrm{MJ} / \mathrm{year}) \\
\mathrm{X} \text { green energy unit price }(\mathrm{yen} / \mathrm{MJ})\end{array}$ & $\begin{array}{l}\text { Green energy unit price set (e.g., 15yen/kWh) } \\
\text { "Examination Committee on VER Japanese Certification } \\
\text { Standards Used in Carbon Offsets" } \\
\text { (for photovoltaic power generation) }\end{array}$ \\
\hline \multicolumn{3}{|c|}{ b. Benefit from the ripple effect on the regional economy } \\
\hline $\begin{array}{l}\text { b1. Economic ripple effect from } \\
\text { infrastructure construction } \\
\text { investment }\end{array}$ & $\begin{array}{l}\text { Economic ripple effect from infrastructure construction } \\
\text { investment (yen/year) } \\
=\text { initial infrastructure construction investment (yen) } \\
X \text { gross value added ratio } \div \text { ripple effect period (years) }\end{array}$ & $\begin{array}{l}\text { Gross value added ratio set (e.g., } 0.5) \text { with reference to public } \\
\text { investment gross value added estimates from various industry- } \\
\text { related analyses by local governments } \\
\text { Ripple effect period set at } 70 \% \text { of the lifetime of business } \\
\text { facilities lifetime (e.g., } 10.5 \text { years } \sim 31.5 \text { years) } \\
\end{array}$ \\
\hline $\begin{array}{l}\text { b2. Economic ripple effect on } \\
\text { business operations }\end{array}$ & $\begin{array}{l}\text { Economic ripple effect on business operations (yen/year) } \\
=\text { business operating expenses (yen/year) } \\
\\
X \text { (ripple effect multiplier }-1)\end{array}$ & $\begin{array}{l}\text { Ripple effect multiplier set (e.g. 1.3) with reference to public } \\
\text { works ripple effect multiplier, estimates from various industry- } \\
\text { related analyses by local governments }\end{array}$ \\
\hline $\begin{array}{l}\text { b3. Increased real estate value effect } \\
\text { (residential property) }\end{array}$ & \multirow[b]{2}{*}{$\begin{array}{l}\text { Area real estate value increase effect }(¥ / \text { year) } \\
=\text { standard land price }\left(\text { yen/m/ } \mathrm{m}^{2}\right) \\
X \text { subject land area }\left(\mathrm{m}^{2}\right) \\
\times \text { (real-estate--value increase rate }(\%) / 100) \\
\div \text { increase effect period (years) }\end{array}$} & \multirow{2}{*}{$\begin{array}{l}\text { Standard land price uses the figures from Ministry of Internal } \\
\text { Affairs and Communications, Statistics Bureau, "2009 Statistics } \\
\text { on Cities, Wards, Towns and Villages" } \\
\text { Real estate value increase rate set (e.g., } 0.5 \% \text { ) with reference to } \\
\text { the rent increase rate (0-5\% for model case rent) in the "CASBEE } \\
\text { Real Estate Use Manual (provisionalversion) (July 2009)" } \\
\text { Increase effect period set at } 70 \% \text { of the lifetime of business } \\
\text { facilities lifetime (e.g., } 10.5 \text { years } ~ 31.5 \text { years) }\end{array}$} \\
\hline $\begin{array}{l}\text { b4. Increased real estate value effect } \\
\text { (commercial property) }\end{array}$ & & \\
\hline \multicolumn{3}{|l|}{ c. Benefit from risk aversion } \\
\hline $\begin{array}{l}\text { c1. Contribution to the business and } \\
\text { living continuity plan (BLCP); } \\
\text { energy supply interruption } \\
\text { aversion effect }\end{array}$ & $\begin{array}{l}\text { Energy supply interruption aversion effect (yen/year) } \\
=\text { energy supply interruption unit damage (yen/kW-hour) } \\
\mathrm{X} \text { decentralized power source capacity (kW) } \\
\mathrm{X} \text { supply interruption period (hours/interruption) } \\
\mathrm{X} \text { damage occurrence probability (times/year) }\end{array}$ & $\begin{array}{l}\text { Supply interruption damage (yen/kW-hour), } \\
\text { Supply interruption period (hours/interruption) } \\
\text { Damage occurrence probability (times/year) } \\
\text { set considering prior research's) }\end{array}$ \\
\hline $\begin{array}{l}\text { c2. Risk aversion effect from stronger } \\
\text { regulatory system, higher } \\
\text { standards, etc. }\end{array}$ & $\begin{array}{l}\text { Riskaversion effect from stronger regulatory system } \\
\text { (yen/year) } \\
=\text { utilities expenses (yen/year) } \\
\quad \mathrm{X} \text { risk aversion expense ratio } \div 100\end{array}$ & $\begin{array}{l}\text { Risk aversion expense ratio set with reference to "Sumitomo } \\
\text { Trust \& Banking Co. Ltd. "Outline of Business Awareness Survey } \\
\text { Regarding Environmental Buildings" (July 2009) }\end{array}$ \\
\hline $\begin{array}{l}\text { c3. Health damage risk aversion } \\
\text { effect (residential sector) }\end{array}$ & $\begin{array}{l}\text { Health damage risk aversion effect (yen/year) } \\
=\text { insurance benefits (yen/person) } \\
X \text { subject population (persons) X occurrence ratio }\end{array}$ & $\begin{array}{l}\text { Insurance benefits set using the figures from Japan Institute of } \\
\text { Life Insurance "Nationwide Life Insurance Fact Survey" (e.g., } \\
20.33 \text { million yen/person for death benefits) } \\
\text { Occurrence ratio set (e.g., } 0.01 \% \text { ) Tokyo Medical Examiner's } \\
\text { Office) }\end{array}$ \\
\hline $\begin{array}{l}\text { c4. Health damage risk aversion } \\
\text { effect (commercial sector) }\end{array}$ & $\begin{array}{l}\text { Health damage risk aversion effect (yen/year) } \\
=\text { work absence ratio (days/person-year) } \\
X \text { salary income (yen/year-person) } \\
\div \text { work days (days/year) } X \text { affected persons (persons) } \\
X \text { occurrence probability }\end{array}$ & $\begin{array}{l}\text { Salary income uses figures from National Tax Agency "Fiscal } \\
2005 \text { Salary Income Survey" (e.g., nationwide average of } ¥ 4.37 \\
\text { million/person [including bonuses, etc.]) }\end{array}$ \\
\hline \multicolumn{3}{|c|}{ d. Benefit from the diffusion and education effect } \\
\hline $\begin{array}{l}\text { d1. Leading model project public } \\
\text { awareness and education effect }\end{array}$ & $\begin{array}{l}\text { Public awareness and education effect (yen/year) } \\
=\text { subject population (persons) } \\
X \text { cost required for public awareness and education } \\
\text { ( }(\text { /person-year) } \\
X \text { effective period coefficient }\end{array}$ & $\begin{array}{l}\text { Subject population is the population residing in the subject } \\
\text { district } \\
\text { Cost required for public awareness and education set (e.g. } \\
3,000 \text { yen/person) referring to the costs for attending seminars } \\
\text { implemented by non-profit organizations } \\
\text { Effective period coefficient set (e.g., } 3 \text { years, } 10 \text { years) as the } \\
\text { ratio of the periods in which projects are still leading projects }\end{array}$ \\
\hline $\begin{array}{l}\text { d2. Leading model project advertising } \\
\text { and publicity effect }\end{array}$ & $\begin{array}{l}\text { Advertising and publicity effect (yen/year) } \\
=\text { costs required for the measure (yen/year) } \\
X \text { advertising and publicity effect coefficient } \\
X \text { effective period coefficient }\end{array}$ & $\begin{array}{l}\text { Advertising and publicity effect coefficient set (e.g., } 2 \% \text { ) } \\
\text { referring to the cases (e.g., an effect equivalentt } 2 \% \text { of total } \\
\text { environment-related costs) for company case studies "FY2005 } \\
\text { Environmental Accounting Guidelines Reference Materials" } \\
\text { Effective Period Coefficient set the same as in d1 }\end{array}$ \\
\hline \multicolumn{3}{|c|}{ e. Benefit from improving the living and working environment } \\
\hline $\begin{array}{l}\text { e1. Higher worker intellectual } \\
\text { productivity effect }\end{array}$ & $\begin{array}{l}\text { Higher worker intellectual productivity effect (yen/year) } \\
=\text { affected persons (persons) } \\
\text { X personnel expenses (yen/person-year) } \\
\text { X productivity improvement coefficient } \\
\text { X effective period coefficient }\end{array}$ & $\begin{array}{l}\text { Productivity Improvement Coefficient set (e.g., average of } 0.5 \% \text { ) } \\
\text { referring to the case study analysis (16 environmental buildings in } \\
\text { the U.K. with an intellectual productivity change ranging from } \\
-10 \% \text { to }+11 \% \text { ) in Diana Urge-Vorsatz, et al., "Mitigating } \mathrm{CO}_{2} \\
\text { Emissions from Energy Use in the World's Buildings," Building } \\
\text { Research \& Information (2007) } 35(4) \text {, pp. } 379-398 \\
\end{array}$ \\
\hline e2. Resident health promotion effect & $\begin{array}{l}\text { Residents' health promotion effect (yen/year) } \\
\text { = subject persons (persons) } \\
X \text { amount intended to spend (yen/person-year) } \\
X \text { effective period coefficient }\end{array}$ & $\begin{array}{l}\text { Subject persons are the number of residents in the subject } \\
\text { district } \\
\text { Amount intended to spend is set based on a questionnaire } \\
\text { survey of the residents }\end{array}$ \\
\hline
\end{tabular}




\section{Case study}

A case study of implementation on a specific district was conducted using the evaluation policy presented above.

\subsection{Overview of the case-study district}

Fig.3 presents an outline of the case-study-subject district. The district (hereafter, "District A") is an existing mixed-use urban area centered around a large train station and offices, stores, housing, hotels, universities and other facilities, and an incineration plant located nearby. The case study assumes the following infrastructure arrangement of the District A energy system, as district-scale measures, together with other carbon reduction measures at the individual building level, considering the presence of the incineration plant, which is an unused energy source nearby, as well as area-wide energy utilization that is already being implemented in part of the District.

1) Area-wide utilization of unused high-temperature energy sources (incineration plant heat)

2) Development of area cogeneration as a foundation of an area-wide energy system, together with area-wide development within the district

3) Formation of a smart energy network for the effective use of heat and electricity in response to demand fluctuations, with linkage to the existing district heating and cooling infrastructure

\section{District A Overview}

District with a high concentration of large-capacity, primarily commercial buildings

- District area: 398ha

- Building floor space: 8.8 million $\mathrm{m}^{2}$

- Population: 40,700 persons

- Households: 22,000
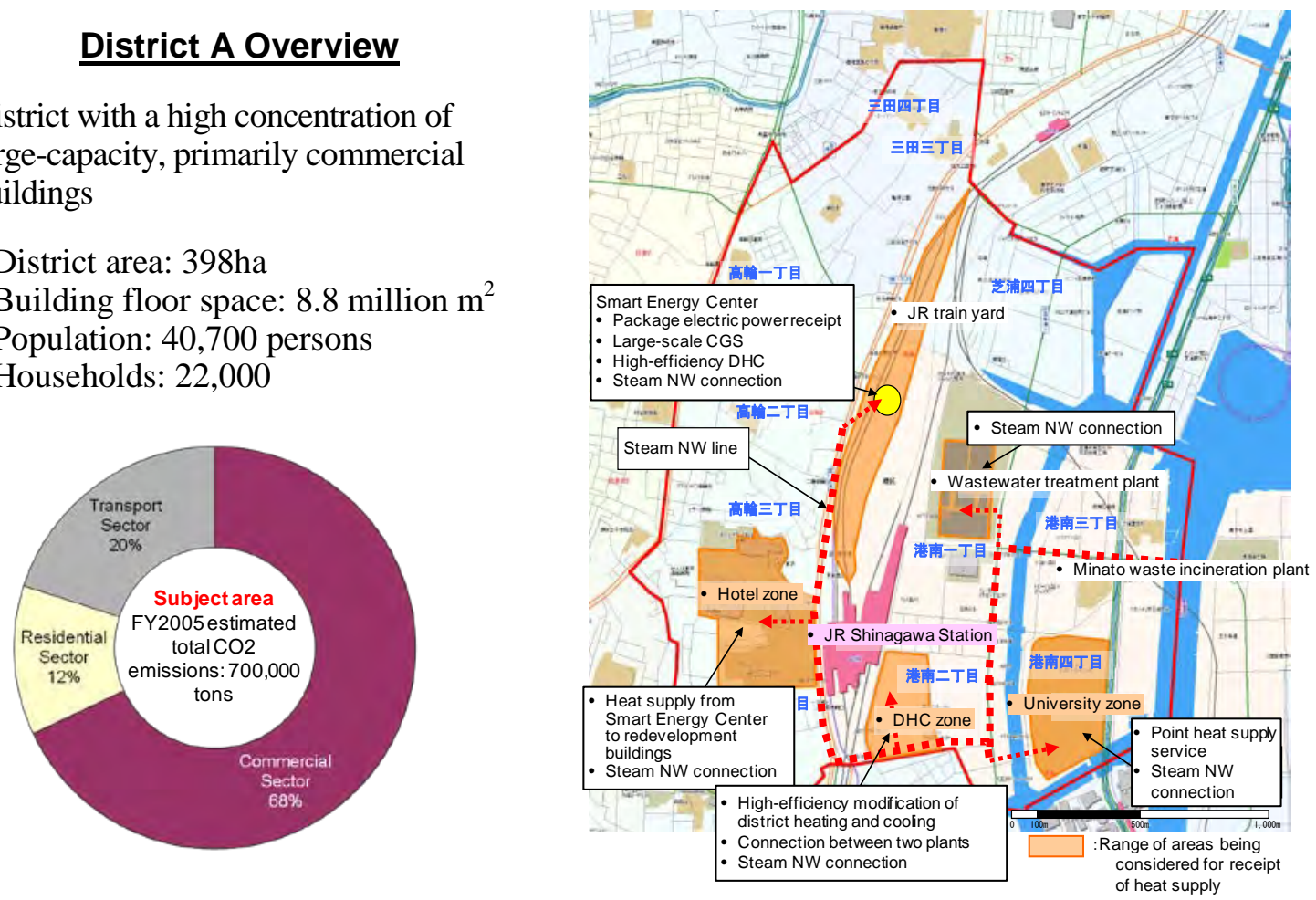

Fig.3. Case study district characteristics and annual $\mathrm{CO}_{2}$ emissions breakdown

\subsection{Carbon reduction measures and $\mathrm{CO}_{2}$ reduction potential}

Carbon reduction measures and the $\mathrm{CO}_{2}$ reduction potential considering that the characteristics of District A are estimated based referring the 2008 (Japanese) Local Government White Paper on the Environment ${ }^{7)}$. The total $\mathrm{CO}_{2}$ reduction potential of all the assumed carbon reduction measures is approximately $160,000 \mathrm{t}-\mathrm{CO}_{2} /$ year. 


\subsection{Results - Cost-benefit ratio $(B / C)$ considering NEBs}

Fig.4 presents the cost-benefit ratio (B/C) trial calculation results for District A, considering NEBs. The total cost when all the measures are implemented is about 4.8 billion yen/y, the EB is approximately 3.7 billion yen/y, and the total monetized NEB is about 4.3 billion yen/y. The $\mathrm{B} / \mathrm{C}$ is just 0.77 when only the $\mathrm{EB}$ is included, but rises to 1.7 when the NEBs are also considered.

\subsection{Results - Marginal abatement cost curve considering $N E B s$}

Fig.5, Fig.6 and Fig.7 present the results of estimated MAC curves. Fig. 5 shows the MAC calculated with uniform payback time of 3 years, or of about 10 years. Fig. 6 shows the results calculated by use of payback time set at $70 \%$ of the functional lifetime of the measures. Fig.7 is the result by considering the NEBs allocated to MAC of each measure in addition to Fig. 6.

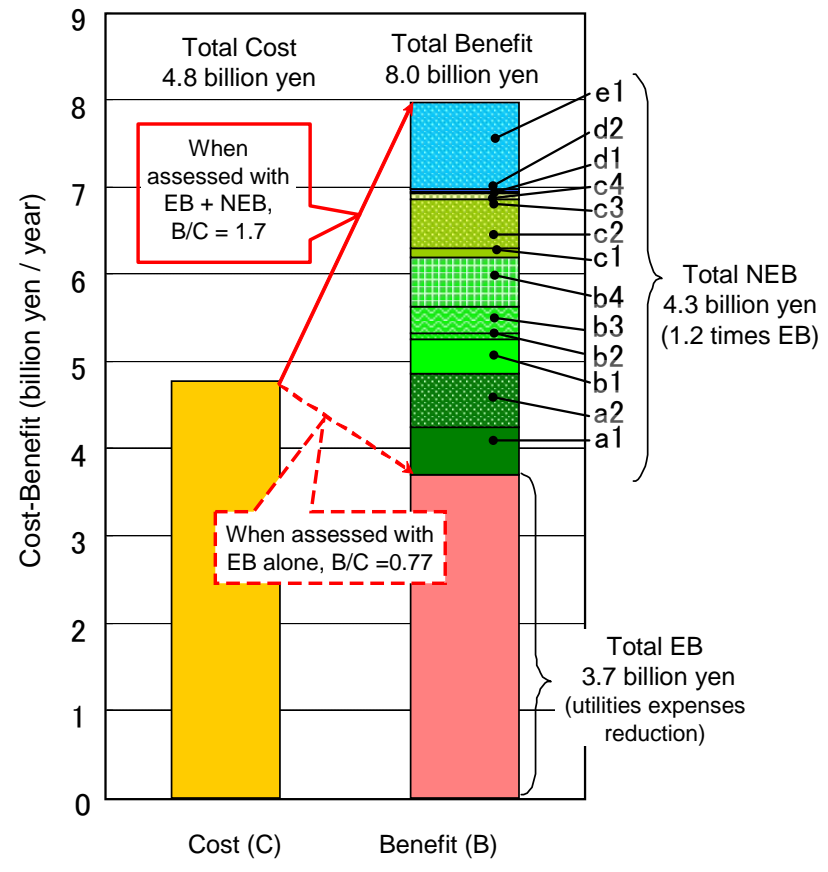

Fig.4. Total cost-benefit ratio $(B / C)$

As shown by the cross-hatched sections of each figure, in District A, arranging communitywide energy utilization by making use of the regional characteristics (including the effective use of incineration plant waste heat and the existing district heating and cooling network) has a high economic priority.

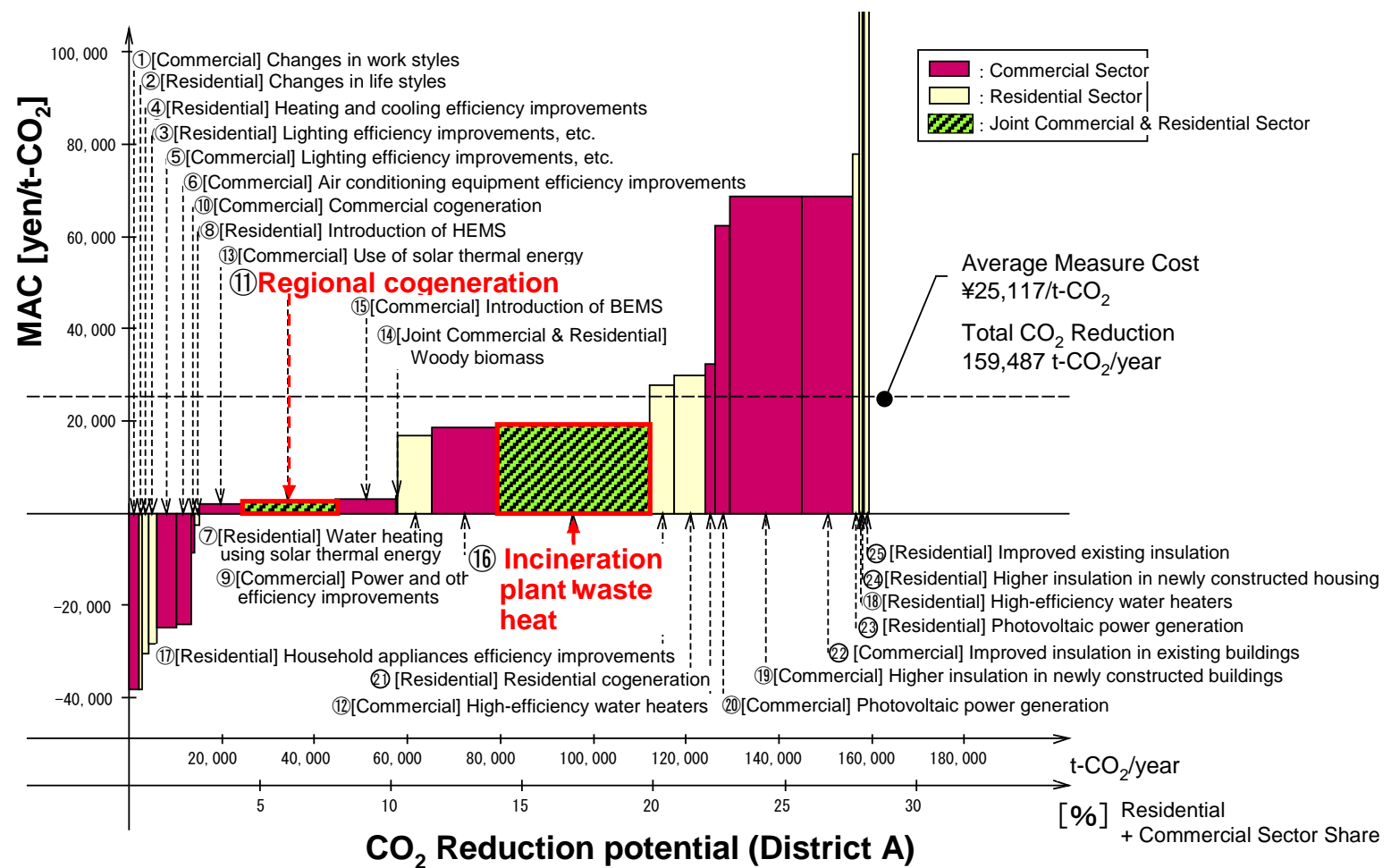

Fig.5. District A's marginal abatement cost curve (Uniform payback time of 3 years, or of about 10 years) 
Comparison between Fig 5 and Fig6, it is clearly shown how setting the payback time appropriately for each measure greatly decreases the average cost of the measures ( 25,117 -> 6,739yen/t- $-\mathrm{CO}_{2}$ ).

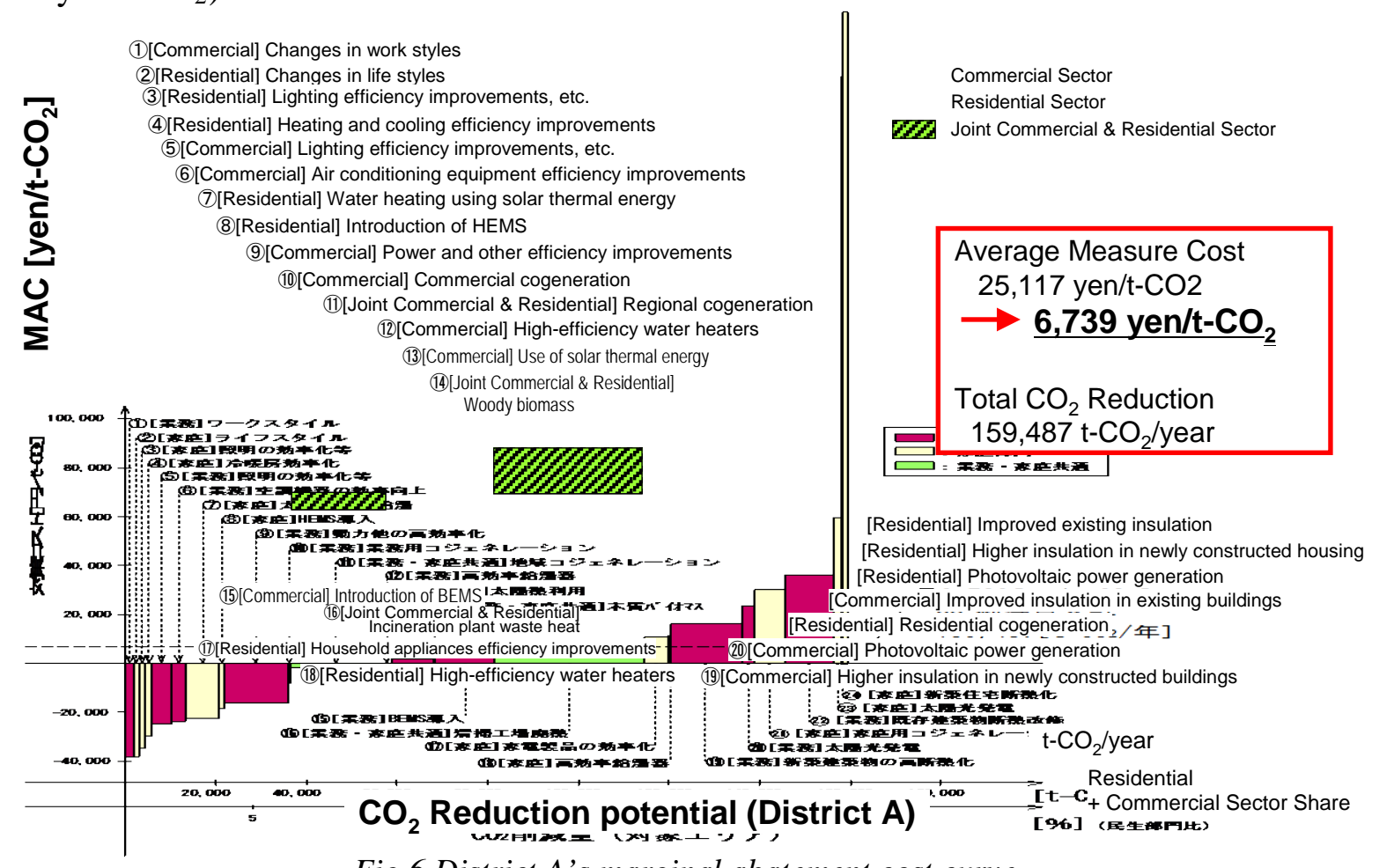

Fig.6 District A's marginal abatement cost curve (payback time set at $70 \%$ of the measure lifetime)

In addition, by reflecting the NEB to Fig.6, as Fig.7 shows, the MAC becomes negative for most measures (i.e., the benefits exceed the expenses over the payback time), and the average measure cost is estimated at around ( +6,739 -> -20,006 yen/t- $\left.\mathrm{CO}_{2}\right)$.

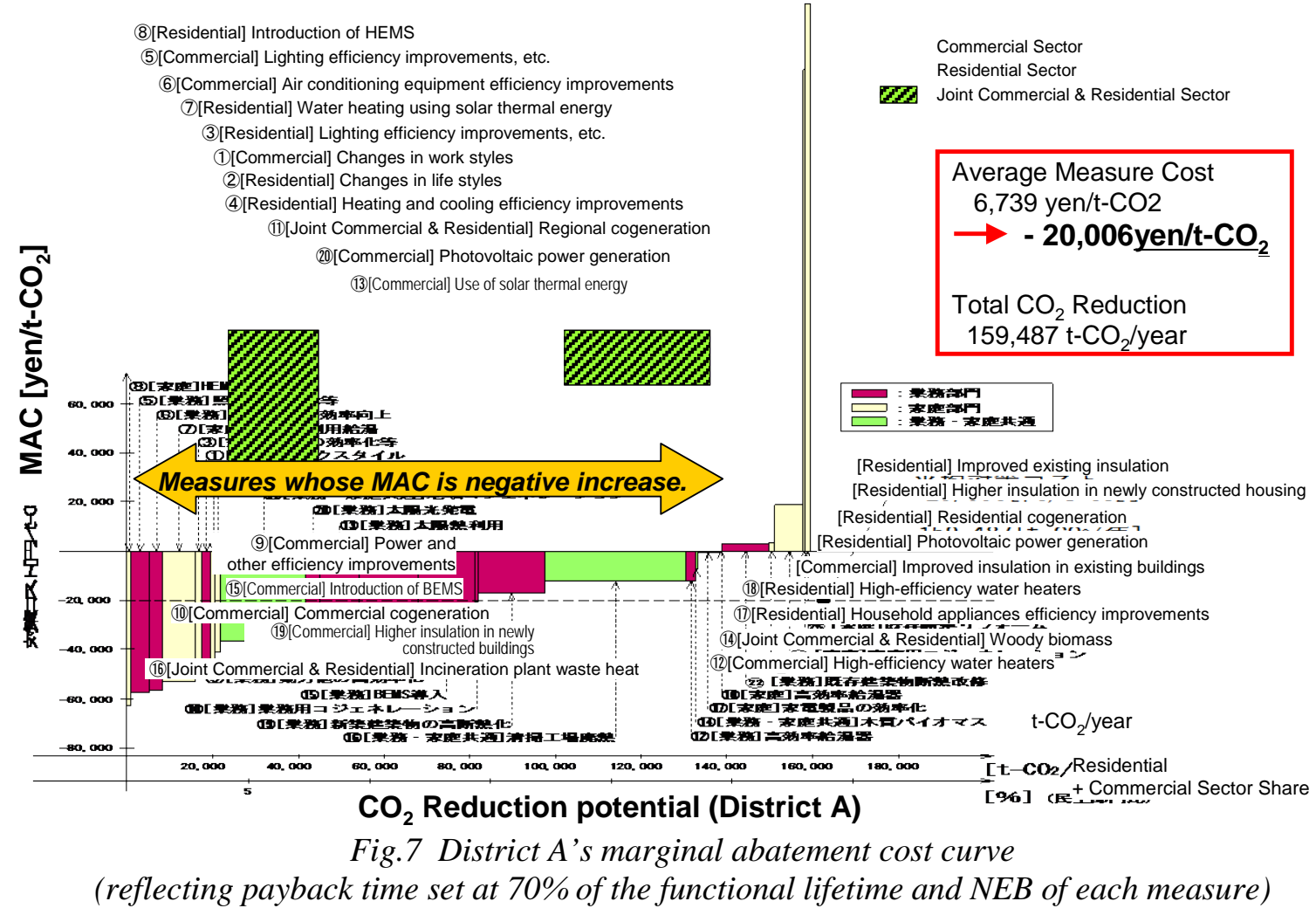




\section{Conclusion}

To promote area-wide energy management, this study proposes the approach of using a marginal abatement cost (MAC) from a middle-term and long-term perspective and conducting cost-benefit ratio $(\mathrm{B} / \mathrm{C})$ calculations considering the non-energy benefits (NEBs) generated from various carbon reduction measures. The findings are as below:

1) It was clarified that the $\mathrm{CO}_{2}$ reduction potential of area-wide energy utilization and the utilization of unused energy sources are much competitive measures in the marginal abatement cost curve for a specific district. This was verified through a case study on utilization of incineration-plant waste heat.

2) It is proposed that evaluation of the MAC for each measure should should be used to set the payback time appropriately from the viewpoint of the middle-term and long-term improvement of social capital, with consideration for the conditions under which the technology is used. $70 \%$ of the functional lifetime of the measures is proposed as the payback time. Through a case study, it was clarified that this improves the MAC assessment for measures with high initial investments, such as improving building insulation and area-wide utilization.

3) This study presents an approach to monetizing the non-energy benefits (NEBs) that result from area-wide energy utilization, which can explain a higher B/C. This study also proposes an approach to revising MAC through allocation of the NEBs to each measure, and demonstrates through a case study how this results in the assessment of more of the measures within the subject areas as economically promising.

\section{Acknowledgements}

This paper is part of the results of activities conducted by the Carbon-Minus High-Quality Town Research Committee, established with the Japan Sustainable Building Consortium as the secretariat. The authors would like to express their gratitude to all the concerned parties for their contributions.

\section{References}

[1] Cabinet Secretariat Japan, Global Warming Prevention Headquarters, "Kyoto Protocol Target Achievement Plan,” April 2005

[2] Cabinet Secretariat Japan, Council on the Global Warming Issue: submitted papers at “Mid-term Targets Examination Committee” (Nov. 2008 - April 2009).

[3] McKinsey \& Company: "Pathways to a Low-Carbon Economy: Version 2 of the Global Greenhouse Gas Abatement Cost Curve,” January 2009

[4] Bement Dawn and Lisa A. Skumatz: "New Non-Energy Benefits (NEBs) Results in the Commercial/Industrial sectors," ECEEE 2007 Summer Study Proceedings, pp.15511559, June 2007

[5] R. Kuzuki, S. Murakami, et. al.: Improving Sustainability of Building Blocks by Extended Use of Decentralized Combined Heat and Power Systems, Proceedings of the 2008 World Sustainable Building Conference Vol.2, pp.3347-3354, 2008.12

[6] Central Environment Council, Global Environment Committee, Targets Reduction Scenario Subcommittee, Mid-term Report, June 2001

[7] Coalition of Japanese Local Governments for Environment Initiative and the Institute for Environmental Planning Inc., "2008 Local Government White Paper on the Environment,” Coalition of Local Governments for Environment Initiative Secretariat, May 2008 